EMSP \#86803

\title{
Underground Corrosion after 32 Years: A Study of Fate and Transport
}

\section{Research O bjective}

In 1970, the National Institute of Standards and Technology (NIST) implemented the most ambitious and comprehensive long-term corrosion behavior test to date for stainless steels in soil environments. Over 32 years have passed since scientists buried 6,324 specimens from stainless steel types, specialty alloys, composite configurations, and multiple material forms and treatment conditions at six distinctive soil-type sites throughout the country. Today, there are more than 190 specimens per site, exceeding a total of 1000 specimens that remain undisturbed, a buried treasure of subsurface scientific data.

This research project advocates the completion of the NIST corrosion study along with a thorough examination of the soil and environment surrounding the specimens. The project takes an interdisciplinary research approach that will correlate the complicated interrelationships among metal integrity, corrosion rates, corrosion mechanisms, soil properties, soil microbiology, plant and animal interaction with corrosion products, and fate and transport of metallic ions. The results will provide much-needed data on corrosion rates, underground material degradation, and the behavior of corrosion products in the near-field vadose zone. The data will improve the ability to predict the fate and transport of chemical and radiological contaminants at sites throughout the DOE complex. The research scope of work is limited to one of the six available sites.

\section{Research Progress and Implications}

As of J une 1, 2003, the 3-year Environmental Management Science Program (EMSP) research project \#86803 has been in progress for 8 months. The initial activities consisted of obtaining historical background and any data from the original test that may have survived at NIST. During the first three months of the project, contact was made at each of the six National Bureau of Standards (NBS) sites as well as with NIST and the surviving NBS corrosion test investigator, Edward Escalante.

Points-of-contact were established and confirmation from those points-of-contact revealed test remnants at five of the six sites (i.e., A, B, C, D, and E). Current status and viability of the Sites is shown in Section 5 , Table 2, along with selected photos from Site A, B and D.

The NIST contacts provided all available documentation references and existing data that survived the years (see Table 1). Unfortunately, some of the original data (e.g., the original mass and sizes, with corresponding identification) are missing or lost. The implication of this loss of original data will increase the 
uncertainties in the measured values since the original mass of the specimens will need to be calculated based on physical measurements and density values.

Table 1. Research-related reference documentation

\begin{tabular}{|l|l|}
\hline Publication Title & Reference \\
\hline $\begin{array}{l}\text { Progress Report on Corrosion } \\
\text { Behavior of Selected Stainless Steels } \\
\text { in Soil Environments }\end{array}$ & W.F. Gerhold, E. Escalante, and B.T. \\
\hline Sanderson, NBSIR 76-1081, 1976 \\
\hline $\begin{array}{l}\text { The Corrosion Behavior of Selected } \\
\text { Stainless Steels in Soil Environments }\end{array}$ & W.F. Gerhold, E. Escalante, and B.T. \\
\hline $\begin{array}{l}\text { Galvanic Coupling of Some Stressed } \\
\text { Stainless steels to Dissimilar Metals } \\
\text { Underground, Galvanic and Pitting } \\
\begin{array}{l}\text { Corrosion - Field and Laboratory } \\
\text { Studies }\end{array}\end{array}$ & \\
\hline
\end{tabular}

To coordinate the different disciplines working this research project, a detailed analytical activity chart was devised using a systems engineering approach. This top down /bottom up gap analysis approach was accomplished as a predecessor to structuring a team meeting to decide on the priorities of both the sampling and analysis work.

This research involves the cooperation and interface with at least one property or land holder to obtain permission to access the land where the specimens are buried, recover both the specimens and the associated environmental samples in the direct vicinity of the specimens, then reestablish the grade and vegetation.

The Toppenish location ( $S$ ite $A$ ), as indicated in the proposal, is the preferred site. This site has advantages for DOE as an analog site for several DOE Complex cleanup and operational sites in the Western part of the U.S. Additional interest in this particular site, particularly from a colloidal transport study, has been expressed by Yucca Mountain scientists. The land is part of the "closed" Yakama Tribal lands. The project has established a very positive working relationship with the Yakama Indian Nation point-of-contact, and the Tribal Council has had the project on the Council agenda twice. Although some initial sensitivity was voiced regarding the intentions of the research project, the Tribal Council has now allowed us to pursue a Memorandum of Agreement (MOA) to establish the limits of the Site A research activities. The agreement will be a valuable tool for cooperation and collaboration with the Yakama Nation. The MOA should be drafted and through all of the necessary Yakama committees by the first part of J uly. Timing the mobilization of the team for the excavation and subsequent analysis will depend on when the MOA is finalized.

In the event the Yakama Nation chooses not to collaborate, an alternate site, namely, Site B at the Loch Raven Reservoir, has been selected. An activity is being pursued to establish a Right of Entry Permit and any other environmental permitting necessary to use the site. 


\section{Planned Activities}

- J une $26^{\text {th }}$ - Travel to Maryland and New J ersey to visit Sites B, C, D, E and G. Establish communication for obtaining Right of Entry with $S$ ite $B$.

- J uly $10^{\text {th }}$ - Obtain MOA Draft from Yakama Indian Nation and pursue review at INEEL.

- J une 16-J uly 31 - Draft Sampling/Excavation plan and review with team.

- August-Finalize Site planning and team review and concurrence. Site surface survey.

- September - Optimally, recovery of the specimens and environmental samples would occur during the month of September, as this is the anniversary of when the specimens were emplaced. However, timing of the field work is dependent on many factors, including field and weather conditions. If conditions are not reasonable to ensure safe field work, then the field work will be postponed until such time as is reasonable in the following Spring.

- FY $04 \&$ FY 05 - Analysis work will be the top priority as determined by sampling and analysis planning.

- FY 05 - Modeling of results and final reporting.

\section{Information Access}

Pending: ASM International update Volume 13, Simulated Service Testing in Soil.

by M. K. Adler Flitton, INEEL and E.Escalante

Update of lastest handbook - due for publication late June or July 2003.

\section{Optional Additional Information}

Table 2. NBS Test Sites.

\begin{tabular}{|c|c|c|c|c|}
\hline $\begin{array}{c}\text { Site } \\
\text { Details } \\
\text { Soil }\end{array}$ & Location & Landowner & $\begin{array}{c}\text { Status of } \\
\text { Specimens }\end{array}$ & Site Access \\
\hline $\begin{array}{l}\text { Site A, } \\
\text { Sagemoor } \\
\text { Sandy } \\
\text { Loam, salt } \\
\text { grass and } \\
\text { short brush }\end{array}$ & $\begin{array}{l}\text { About 18- } \\
\text { miles } \\
\text { southwest } \\
\text { of } \\
\text { Toppenish, } \\
\text { WA }\end{array}$ & $\begin{array}{l}\text { Yakama } \\
\text { Indian Nation }\end{array}$ & $\begin{array}{l}\text { Site visited } \\
\text { and } \\
\text { photographed. } \\
\text { Many trench } \\
\text { markers (4X4) } \\
\text { posts are still } \\
\text { standing in } \\
\text { the ground. }\end{array}$ & $\begin{array}{l}\text { Site access for specimen removal } \\
\text { is in process and pending. A } \\
\text { Memorandum of Agreement } \\
\text { between the INEEL and the } \\
\text { Yakama Indian Nation is being } \\
\text { generated by the tribal legal } \\
\text { council and is pending. }\end{array}$ \\
\hline
\end{tabular}




\begin{tabular}{|c|c|c|c|c|}
\hline $\begin{array}{c}\text { Site } \\
\text { Details } \\
\text { Soil } \\
\end{array}$ & Location & Landowner & $\begin{array}{l}\text { Status of } \\
\text { Specimens }\end{array}$ & Site Access \\
\hline $\begin{array}{l}\text { Site B, } \\
\text { Hagerstown } \\
\text { Loam, } \\
\text { grassy field } \\
\text { next to a } \\
\text { forest }\end{array}$ & $\begin{array}{l}\text { At the Lock } \\
\text { Raven } \\
\text { Reservoir } \\
\text { north of } \\
\text { Baltimore, } \\
\text { MD }\end{array}$ & $\begin{array}{l}\text { Loch Raven } \\
\text { Water Works } \\
\text { and the City of } \\
\text { Baltimore, } \\
\text { MD }\end{array}$ & $\begin{array}{l}\text { Site visit } \\
\text { planned for } \\
6 / 26 / 03 \text {. The } \\
\text { landowner has } \\
\text { identified the } \\
\text { site. Three } \\
\text { trench } \\
\text { markers were } \\
\text { found at the } \\
\text { site. }\end{array}$ & $\begin{array}{l}\text { A right of entry permit to remove } \\
\text { specimens has been submitted to } \\
\text { the Baltimore Water Works for } \\
\text { review and approval. }\end{array}$ \\
\hline $\begin{array}{l}\text { Site C, Clay, } \\
\text { is located in } \\
\text { a wetland } \\
\text { heavily } \\
\text { overgrown } \\
\text { with } \\
\text { Phragmite } \\
\text { an invasive } \\
\text { reed. }\end{array}$ & $\begin{array}{l}\text { On the U.S. } \\
\text { Coast Guard } \\
\text { Receiving } \\
\text { Station at } \\
\text { Cape May, } \\
\text { NJ }\end{array}$ & $\begin{array}{l}\text { U.S. Coast } \\
\text { Guard }\end{array}$ & $\begin{array}{l}\text { Site visit } \\
\text { planned for } \\
6 / 26 / 03 \text {. } \\
\text { Maps made } \\
\text { by NIST } \\
\text { personnel } \\
\text { guided the } \\
\text { landowner to } \\
\text { the site. The } \\
\text { site has been } \\
\text { identified as a } \\
\text { Phragmite } \\
\text { (invasive } \\
\text { reed) } \\
\text { overgrown } \\
\text { wetland. No } \\
\text { photographs } \\
\text { of the site are } \\
\text { currently } \\
\text { available. }\end{array}$ & $\begin{array}{l}\text { Not yet defined. The } 6 / 26 / 03 \\
\text { meeting will cover these details. }\end{array}$ \\
\hline $\begin{array}{l}\text { Site D, } \\
\text { Lakewood } \\
\text { Sand, } \\
\text { heavily } \\
\text { overgrown } \\
\text { with tall } \\
\text { brush and } \\
\text { weeds. }\end{array}$ & $\begin{array}{l}\text { On the U.S. } \\
\text { Coast Guard } \\
\text { Loran } \\
\text { Support } \\
\text { Unit near } \\
\text { Wildwood, } \\
\text { NJ }\end{array}$ & $\begin{array}{l}\text { U.S. Coast } \\
\text { Guard }\end{array}$ & $\begin{array}{l}\text { Site visit } \\
\text { planned for } \\
6 / 26 / 03 \text {. } \\
\text { Maps made } \\
\text { by NIST } \\
\text { personnel } \\
\text { showing the } \\
\text { location of the } \\
\text { site guided the } \\
\text { landowner to } \\
\text { the site. The } \\
\text { location was } \\
\text { identified, and } \\
\text { trench } \\
\text { markers were } \\
\text { found. }\end{array}$ & $\begin{array}{l}\text { Not yet defined. The } 6 / 26 / 03 \\
\text { meeting will cover these details. }\end{array}$ \\
\hline
\end{tabular}




\begin{tabular}{|c|c|c|c|c|}
\hline $\begin{array}{c}\text { Site } \\
\text { Details } \\
\text { Soil } \\
\end{array}$ & Location & Landowner & $\begin{array}{l}\text { Status of } \\
\text { Specimens }\end{array}$ & Site Access \\
\hline $\begin{array}{l}\text { Site E, } \\
\text { Coastal } \\
\text { Sand, sandy } \\
\text { beach }\end{array}$ & $\begin{array}{l}\text { On the U.S. } \\
\text { Coast Guard } \\
\text { Loran } \\
\text { Support } \\
\text { Unit near } \\
\text { Wildwood, } \\
\text { NJ }\end{array}$ & $\begin{array}{l}\text { U.S. Coast } \\
\text { Guard }\end{array}$ & $\begin{array}{l}\text { Site visit } \\
\text { planned for } \\
6 / 26 / 03 \text {. } \\
\text { Maps made } \\
\text { by NIST } \\
\text { personnel } \\
\text { showing the } \\
\text { site location } \\
\text { guided the } \\
\text { landowner to } \\
\text { the site. The } \\
\text { site location } \\
\text { has been } \\
\text { identified and } \\
\text { trench } \\
\text { markers } \\
\text { found, but no } \\
\text { photographs } \\
\text { have been } \\
\text { made. }\end{array}$ & $\begin{array}{l}\text { Not yet defined. The } 6 / 26 / 03 \\
\text { meeting will cover these details. }\end{array}$ \\
\hline $\begin{array}{l}\text { Site G, Tidal } \\
\text { marsh, along } \\
\text { a creek bank } \\
\text { that empties } \\
\text { into the } \\
\text { ocean. The } \\
\text { creek was } \\
\text { recently } \\
\text { dredged } \\
\text { down to } \\
\text { about 12- } \\
\text { feet and } \\
\text { lined with } \\
\text { river rock to } \\
\text { facilitate } \\
\text { flow. }\end{array}$ & $\begin{array}{l}\text { Along the } \\
\text { bank of } \\
\text { Pine Hill } \\
\text { Run Creek } \\
\text { adjacent to } \\
\text { Patuxent } \\
\text { Naval Air } \\
\text { Station near } \\
\text { Lexington } \\
\text { Park, MD }\end{array}$ & $\begin{array}{l}\text { Not known. } \\
\text { Access to the } \\
\text { site is through } \\
\text { the Navy base, } \\
\text { but the site is } \\
\text { located on } \\
\text { land near a } \\
\text { water } \\
\text { treatment plant } \\
\text { that dumps } \\
\text { into a tidal } \\
\text { basin that } \\
\text { drains into the } \\
\text { ocean. }\end{array}$ & $\begin{array}{l}\text { The site was } \\
\text { visited, and it } \\
\text { was } \\
\text { determined } \\
\text { that the site/ } \\
\text { specimens } \\
\text { have been } \\
\text { destroyed. No } \\
\text { markers were } \\
\text { found. Metal } \\
\text { detector } \\
\text { readings did } \\
\text { not indicate } \\
\text { the presence } \\
\text { of buried } \\
\text { metal. }\end{array}$ & Site not viable \\
\hline
\end{tabular}




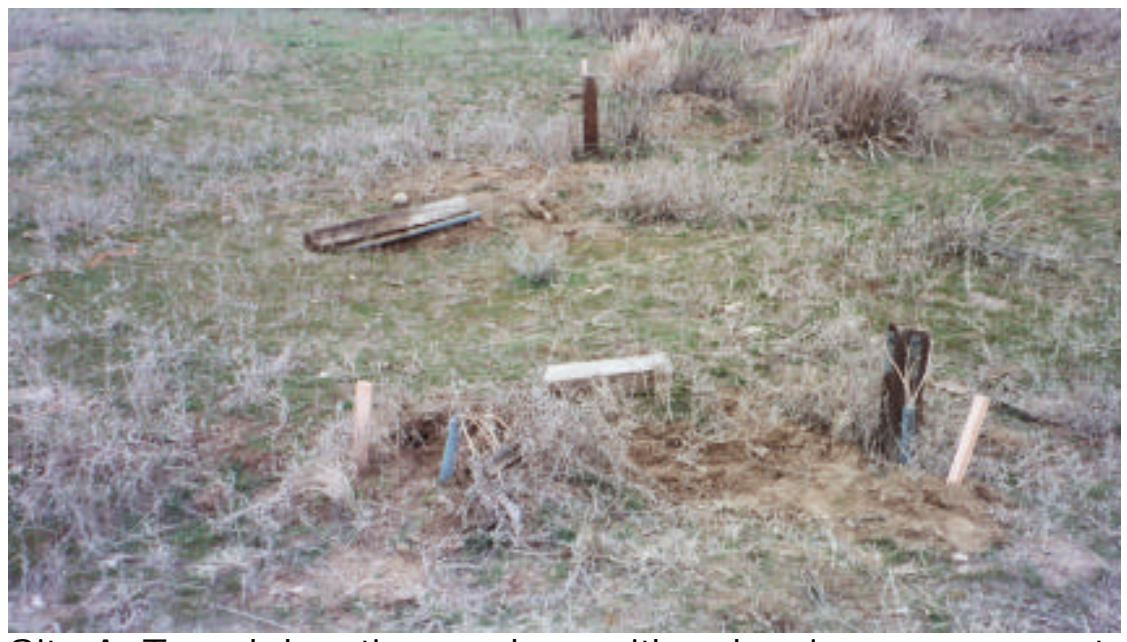

Site A. Trench location markers with galvanic measurement connections. (2-13-03)

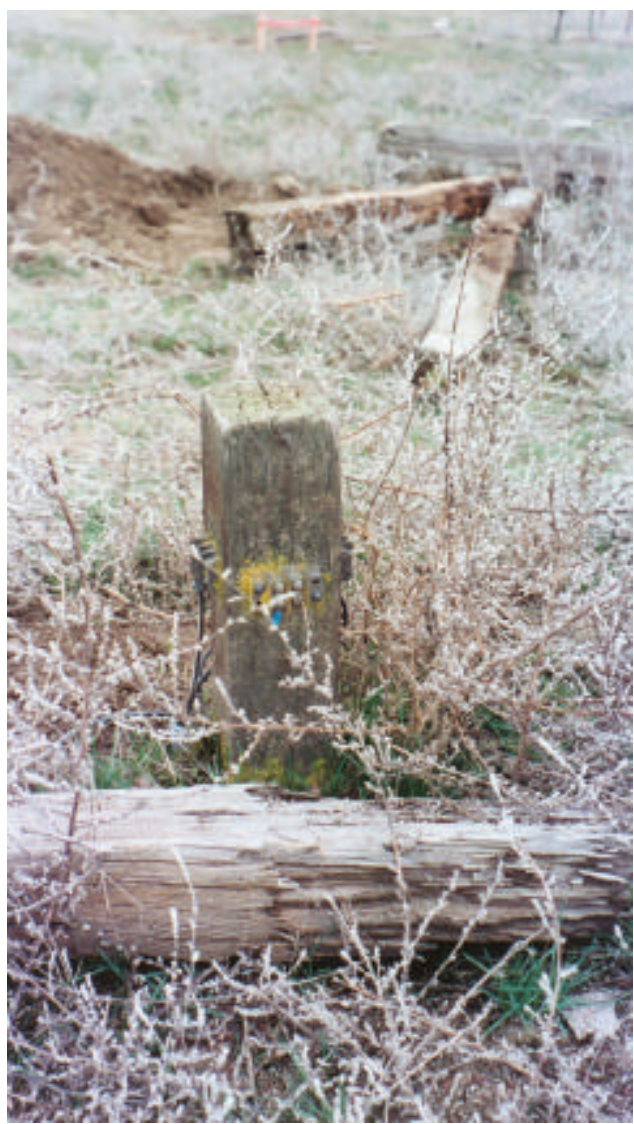

Site A. Location marker. (2-13-03). 


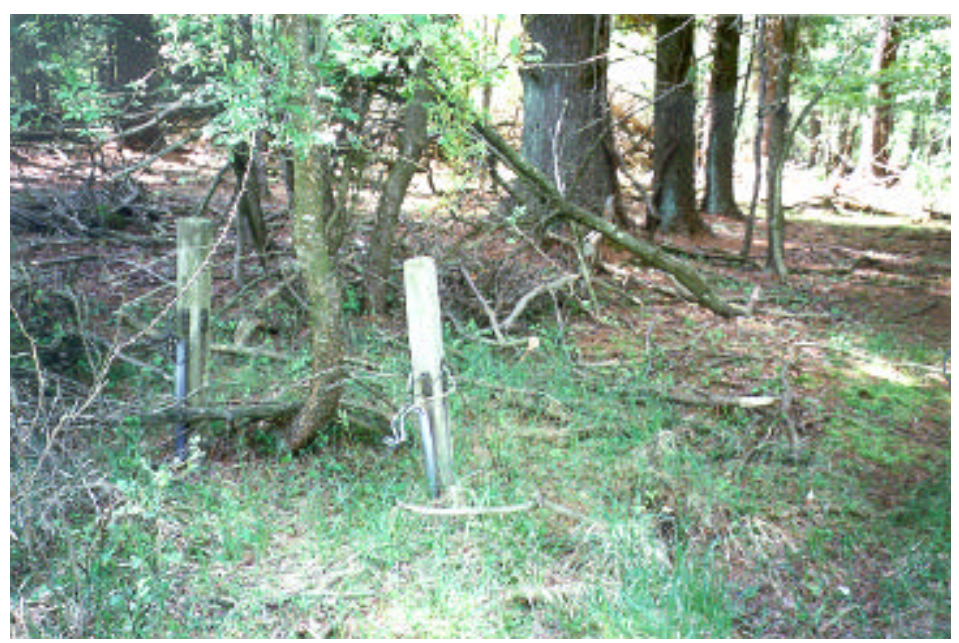

Site B. Location Markers. (5-27-03).

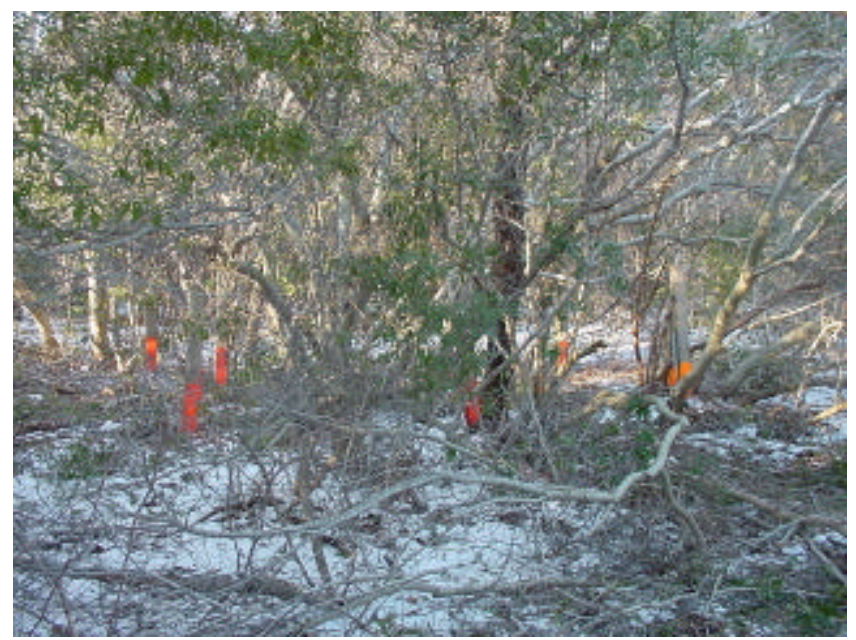

Site D. Location Markers. (3-25-03).

\section{Optional Proprietary Information}

No proprietary information to report at this time. 